PACS: $47.35 .+\mathrm{i} ; 47.35 . \mathrm{Bb}$

\title{
ON FREQUENCY AND SPATIAL PERIODICITY OF THE WAVES OF THE ANOMALOUS AMPLITUDE IN THE OCEAN
}

\author{
(DVolodymyr M. Kuklin, (D)Eugen V. Poklonskiy \\ V.N. Karazin Kharkiv National University, Kharkiv, Ukraine \\ Svobody Sq. 4, Kharkiv, Ukraine, 61022 \\ E-mail:kuklinvm1@gmail.com \\ Received July 31, 2019, accepted October 15, 2019
}

The paper shows that the waves of anomalous amplitude are long-lived formations. They drift in the direction of the wave motion with the group velocity of the wave packet, which is half the phase velocity of the main wave. The swing of the wave (the distance from the hump to the trough) of the anomalous amplitude is more than three times the average value of the sweep of the wave motion. The modulation instability of this wave form a perturbation spectrum, the energy of which is twice the energy of the main wave in the developed process mode. The spatial size of the wave packet practically does not change, the amplitude of the swing in the maximum first increases, then gradually decreases. The number of such waves in areas of strong wind exposure is much larger than the statistics of random interference processes allow. This is due to the influence of the main wave (its amplitude remains noticeably greater than the amplitudes of each of the modes of the wave packet) on the behavior of each pair of modes from the wave packet of the perturbation. In the laboratory system, the duration of the anomalous wave coincides qualitatively with the time of existence of the Peregrin autowave. Although the Peregrin autowave corresponds to a different physical reality, where the dispersion of the wave is weak. Gravitational surface waves have a strong dispersion, and the NSE equation in this case is noticeably modified. However, in rest system of the wave packet (moving relative to the laboratory system) the abnormal amplitude wave lifetime is much longer. The distance that the wave packet travels with a persisting anomalous sweep is at least equal to several hundred wavelengths and can reach hundreds of kilometers. A simple calculation of such waves by means of space monitoring due to the small viewing area (frame) may be inaccurate. Once formed, such waves are able to drift over considerable distances. However, they may well get into the next frame of view. That is, estimates of the number of such waves can be overestimated.

KEYWORDS: long-lived wave of anomalous amplitude, ocean waves, modulation instability.

The actual problem of the safety of shipping and oil and gas production in the oceans and seas is to determine the conditions for the appearance of surface waves of abnormal amplitude that can lead to major disasters and accidents. Earlier, when the intensity of shipping and oil and gas production was not so intense, the occurrence of such waves was considered to be quite rare, and they simply did not consider it necessary to take into account their appearance and impact. However, with an increase in the number of vessels and their personnel, numerous evidences of the appearance of such anomalous waves appeared. However, people are not only worried about the detection of such waves of anomalous amplitude, it is necessary to find out the characteristics of the life cycle of such waves, how long they are able to exist and whether they can move. The purpose of this work is to try to find out the conditions for the existence of waves of anomalous amplitude, the nature of their appearance and the dynamics of propagation.

\section{DESCRIPTION OF SURFACE WAVES IN DEEP WATER}

Large-amplitude surface waves in deep water that cause concern to ocean logistics have a frequency of [1]

$$
\omega=\sqrt{g \cdot k} \cdot\left\{1+|A|^{2} k^{2} / 2\right\}
$$

which approximately corresponds to the Lighthill-NSE equation [2] of the form

$$
\frac{\partial}{\partial t} A=i \omega \cdot\left(1-\frac{1}{2}|A|^{2} \frac{\partial^{2} A}{\partial x^{2}}\right)
$$

where $A=\sum_{K}\left|A_{K}\right| \cdot \exp \left\{-i \omega \cdot t+i\left(k_{0}+K\right) x\right\}$ is the deviation of the surface, $g$ is the acceleration of free fall, with the maximum steepness for stable waves before they collapse $H / \lambda \approx 0.11 \div 0.13$, where $H=2|A|$ is the steepness (span) of the wave, that is, the distance between the upper point of the wave crest and the lower point of the wave trough, $\lambda=2 \pi / k_{0}$ is the wavelength of large amplitude. The width of the spatial instability spectrum under these conditions is not so small; therefore, the equation for the complex slow varying (here the dependence $\propto \exp \left\{-i \omega \cdot t+i \phi_{0}\right\}$ is excluded) field amplitude is represented as $[3,4]$

$$
\frac{\partial A_{K}}{\partial t}=-\delta A_{K}-i\left(\sqrt{g\left(k_{0}+K\right)}-\sqrt{g k_{0}}\right) A_{K}-i \sqrt{g\left(k_{0}+K\right)} \frac{\left(k_{0}+K\right)^{2}}{2}\left\{|A|^{2} A\right\}_{K} .
$$


In the simplest case of a plane wave front, the field of perturbations is written in the form

$$
A(\zeta, \tau)=\left(u_{0}+\sum_{\substack{K \neq 0 \\ K>0}}\left[u_{K} \cdot \exp \left\{+i K \zeta+i\left(\phi_{K}-\phi_{0}\right)\right\}+u_{-K} \cdot \exp \left\{-i K \zeta+i\left(\phi_{-K}-\phi_{0}\right)\right\}\right]\right)
$$

where the following notation is used, $A_{K} /\left|A_{0}\right|=a_{K}=\left|a_{K}\right| \exp \left\{i \phi_{K}\right\}=u_{K} \exp \left\{i \phi_{K}\right\}$,

$$
k_{0} \xi=\zeta, \alpha=k_{0}^{2}\left|A_{0}\right|^{2}, \tau=t \cdot \sqrt{g k_{0}} \frac{k_{0}^{2}\left|A_{0}\right|^{2}}{2}, K \rightarrow K / k_{0}, 2 \phi_{0}-\phi_{K}-\phi_{-K}=\Phi_{K}=\Phi_{-K} .
$$

Spectrum modes are located in the intervals $0<K<2 K_{M a x}$ and $-2 K_{M a x}<-K<0, K=0.3 \cdot \frac{i}{N}, i= \pm(1,2, \ldots N)$, $\alpha=0.05, N=100$. The initial amplitudes $u_{K}(\tau=0)=10^{-3}$, and their phases $\phi_{K}(\tau=0)$ are randomly distributed in the range of $(0-2 \pi)$.

Finally, the system of equations describing the modulation instability of a wave of large amplitude takes the form for the main mode

$$
\begin{aligned}
& \frac{\partial u_{0}}{\partial \tau}+\delta u_{0}+2 u_{0} \sum_{K>0} u_{K} u_{-K} \sin \Phi_{K}=\delta \\
& \frac{\partial \phi_{0}}{\partial \tau}=-u_{0}{ }^{2}-2 \sum_{K>0}\left(u_{K}{ }^{2}+u_{-K}{ }^{2}\right)-2 \sum_{K>0} u_{K} u_{-K} \cos \Phi_{K},
\end{aligned}
$$

and for the modes of the spectrum of the modulation instability developing in this case [5]

$$
\begin{aligned}
& \frac{\partial \phi_{K}}{\partial \tau}=-\frac{2[\sqrt{(1+K)}-1]}{\alpha}-(1+K)^{2.5} \cdot\left\{2 \sum_{K^{\prime} \neq K} u_{K^{\prime}}{ }^{2}+u_{K}{ }^{2}+\frac{u_{-K}}{u_{K}} \sum_{\mathrm{K} \neq K} u_{\mathrm{K}} u_{-\mathrm{K}} \cos \left(\Phi_{\mathrm{K}}-\Phi_{K}\right)\right\}, \\
& \frac{\partial u_{K}}{\partial \tau}=-\delta u_{K}+(1+K)^{2.5} \cdot\left[u_{-K} \cdot u_{0}{ }^{2} \sin \Phi_{K}+2 u_{-K} \sum_{\mathrm{K}>0} u_{\mathrm{K}} u_{-\mathrm{K}} \sin \left(\Phi_{\mathrm{K}}-\Phi_{K}\right)\right],
\end{aligned}
$$

where $\delta$ is the wave decrement, and to maintain the amplitude of the main wave, the same value is on the right-hand side of (5).

Here, the description is used within the framework of the so-called modified S-theory [6], and the interaction occurs only between the modes of the spectrum $\left(k_{n}+k_{-n}=2 k_{0}, k_{S}+k_{-S}=k_{n}+k_{-n}\right)$ that are symmetrical with respect to pumping. In [5], it was shown that direct calculation of equation (2) and model (4) - (8) lead to qualitatively the same results.

In the presented model, the characteristic spatial scale correlates with the wavelength, that is $k_{0} \xi=\zeta$, the time scale is determined by the ratio, that is $\tau=t \cdot \frac{\alpha \cdot \omega}{2}$, the unit of measurement in space is the wavelength, and the unit of measurement in time is the oscillation period multiplied by $\alpha \cdot \pi$.

MODELING OF THE PROCESS OF FORMATION OF WAVES OF THE ANOMALOUS AMPLITUDE

For each point in time, a relative maximum span is calculated: the ratio of the maximum span to the average over the entire space.
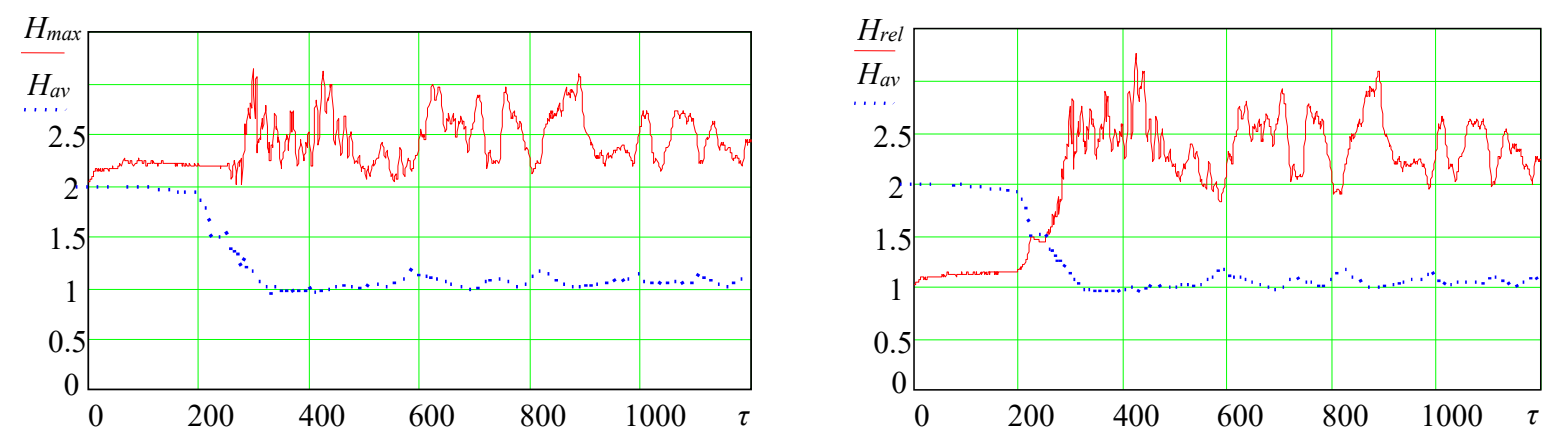

Fig. 1. Behavior of maximum wave span from time $H_{\max }$ (left) and relative maximum wave span $H_{\text {rel }}$ (right) in the interval $-1047<\zeta<1047$ (about 333 wavelengths)

At the initial stage of instability development, an exit to a quasistationary regime occurs with an average swing of wave motion close to unity, which is approximately two times less than the initial value for the main wave. The largest sweep of the waves is reached at the moment of time $\tau=425$ in the region near $\zeta=-482$ and also at the moment of 
time $\tau=888$ near $\zeta=956$. For example, one can imagine phase diagrams and a field view in the vicinity of the swing peak (Fig. 2).
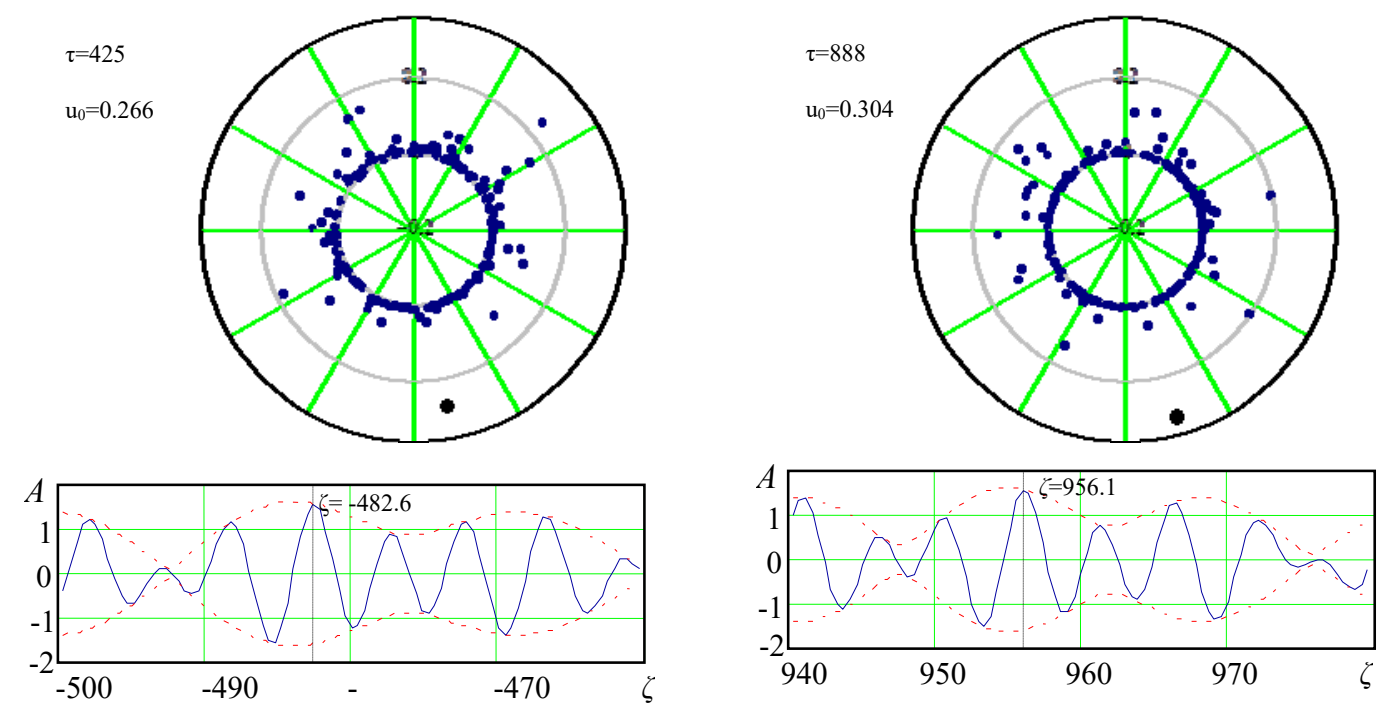

Fig. 2. Phase diagrams and field view near the maxima of the sweeps for the first maximum $H_{\max 1}=3.118 \quad H_{\text {rel } 1}=3.253$ (left) and $H_{\max 1}=3.035 \quad H_{r e l 1}=3.094$ (right)

It should be noted that, although the amplitude of the main wave (the fat point) is not small, it already loses control of the instability. Indeed, in the developed mode, the energy of the main wave is half the energy of the spectrum (Fig. 3), which by the way is characteristic of developed modulation instability modes in other cases [7].

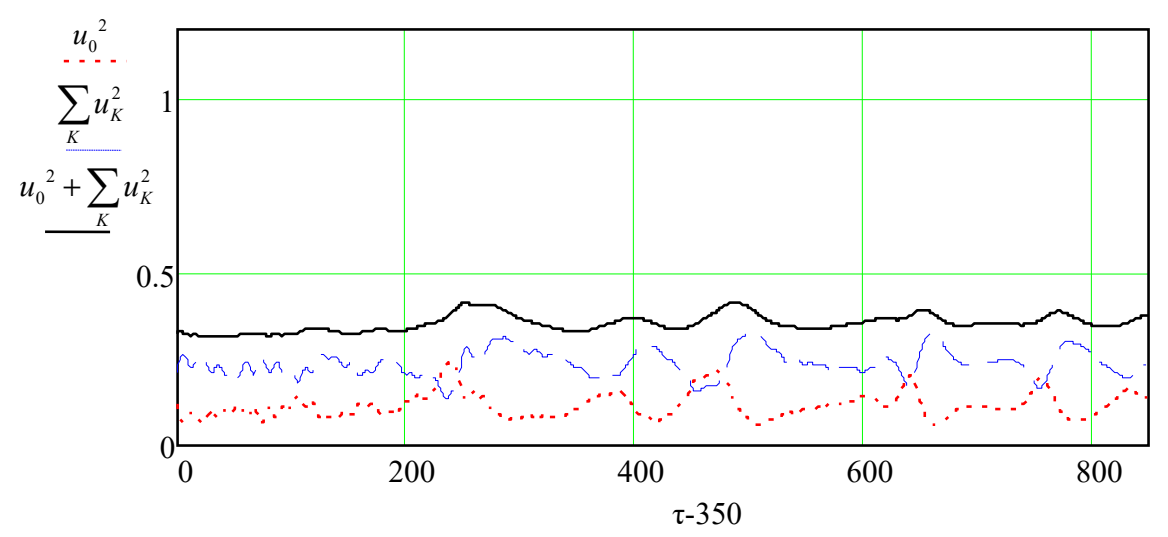

Fig. 3. Behavior in the developed mode of the energy of the main wave $u_{0}^{2}$ (lower curve), energy of the spectrum $\sum_{K} u_{K}^{2}$ (middle curve) and total energy $u_{0}^{2}+\sum_{K} u_{K}^{2}$ (upper curve)

It is of interest to consider the motion of wave packets with a maximum amplitude in space and in time (Fig.4.)
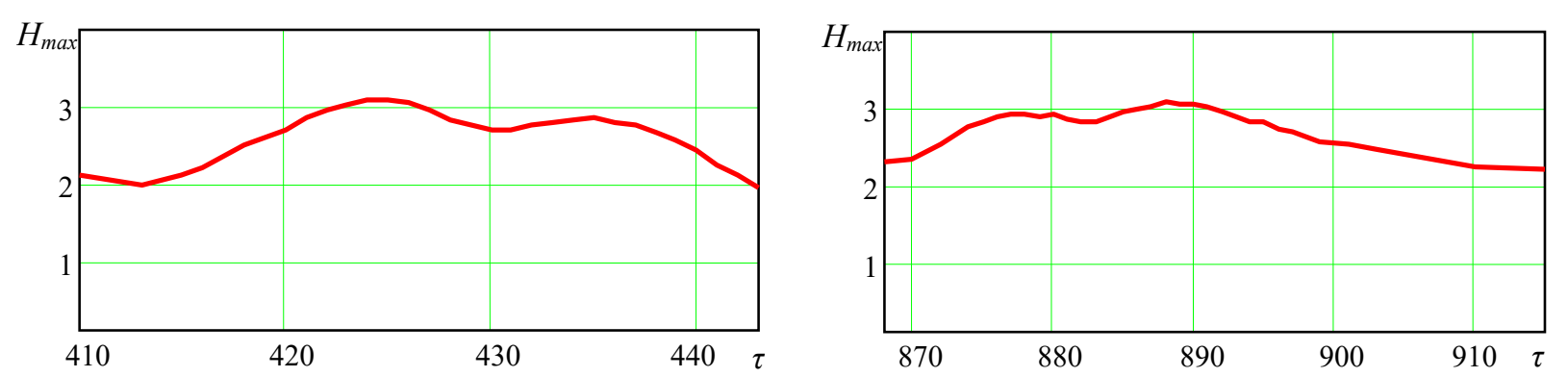

Fig. 4. The change with time of the maximum amplitude of the wave packets near the maximums of swing for the first maximum (left) and (right) 
For the first package (left), the maximum speed in units of model 21.6, for the second package (right) the maximum swing speed is 21.7. That is, the movement of the crest of the anomalous wave occurs at the same speed. This speed is the group velocity of the packet, which is easy to see when considering the ratio from where.

$$
\frac{\partial \zeta}{\partial \tau}=21.6=\frac{\partial x}{\partial t} \cdot \frac{k_{0}}{\omega \cdot(\alpha / 2)}=\frac{v_{g}}{v_{p h}} \cdot \frac{2}{\alpha}, \text { and } \frac{v_{g}}{v_{p h}} \approx 0.54
$$

In the laboratory system, the change in the amplitude of the wave crest of the anomalous amplitude is more pronounced (Fig. 5). This qualitatively corresponds to the duration of the Peregrin autowave [9] in the laboratory reference frame. Although it should be noted that the Peregrin autowave corresponds to a different physical reality, where the dispersion of the wave is weak. It is easy to see that gravitational surface waves from expression (1) have a strong dispersion, and the NSE equation (3) in this case is strongly modified. However, in rest system of the wave packet (moving relative to the laboratory system) the abnormal amplitude wave lifetime is much longer.

From Fig. 4 it can be seen that the time of existence of an abnormal amplitude wave in the reference frame moving with the group velocity of the packet does not exceed 40 units in the model under consideration. Given its speed, a wave can go through hundreds of wavelengths (Fig. 6). It is worth noting that in the considered numerical experiment, at one time point, two waves of anomalous amplitude of 333 waves appeared in the observation area (Fig. 1) and during the time about 40 units of new waves did not occur, then people at sea may encounter this same wave more than once.

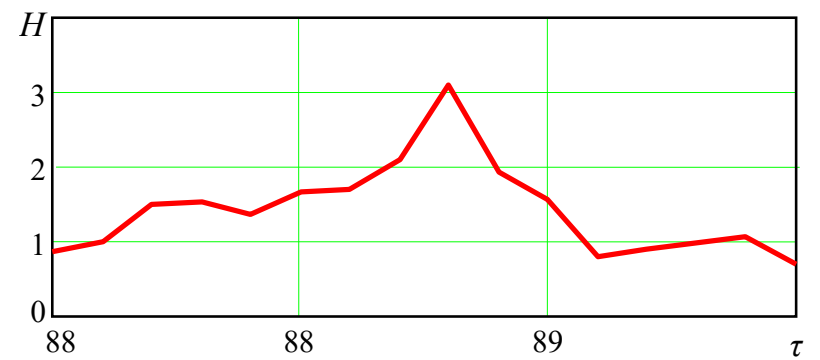

Fig. 5. Changing the amplitude of the wave of anomalous amplitude for the second packet, the maximum values of which were

In conclusion, it is possible to imagine the dynamics of the motion of the wave packet, the maximum range of which reached the highest value at the moment of time $\tau=425$ in the region near $\zeta=-482$.

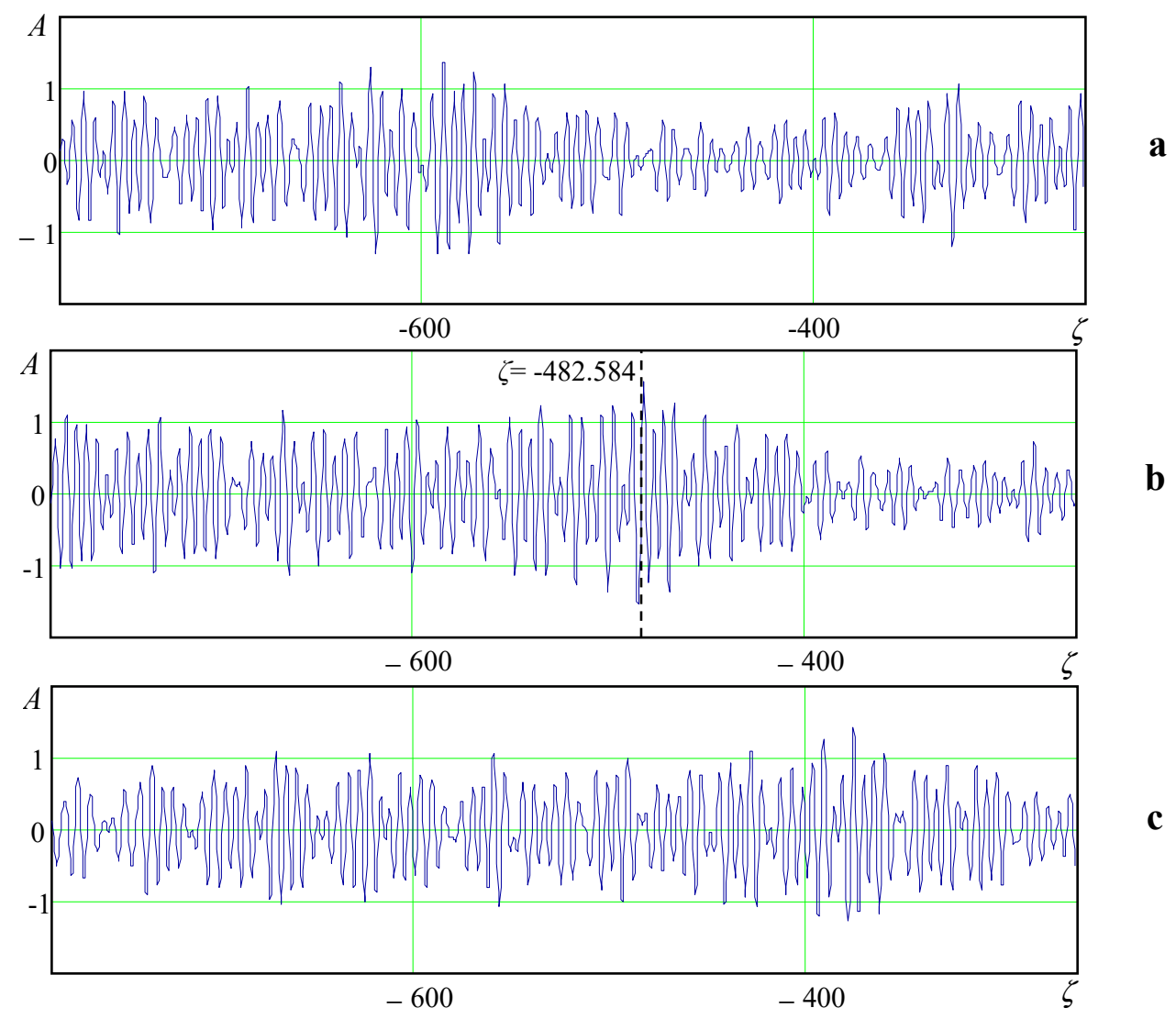

Fig.6. The dynamics of the wave packet, the maximum range of which reached its highest value at the time $\tau=425$ instant in the area near $\zeta=-482$ for time points a) $\tau=420$, b) $\tau=425$, c) $\tau=430$ 


\section{CONCLUSION}

Waves of anomalous amplitude, as it turned out, are long-lived formations drifting in the direction of wave motion with the group velocity of the wave packet, which is half the phase velocity of the main wave. The longitudinal size of the wave packet practically does not change, the amplitude of the swing in the maximum first increases, then gradually decreases. The distance that the wave packet travels with a persisting anomalous sweep is at least equal to several hundred wavelengths and can reach hundreds of kilometers for 300 meter waves.

It is important to note that a wave excited as a result of wind exposure as a result of modulation instability forms a perturbation spectrum, whose energy is twice the energy of the main wave in the developed instability mode. It is the interference of the modes of this spectrum that forms a bizarre wave pattern, where from time to time anomalous amplitude waves appear.

On the one hand, the number of such waves in areas of strong wind exposure is much larger than the statistics of random interference processes allow. This is due to the influence of the main wave (its amplitude remains noticeably greater than the amplitudes of each of the modes of the wave packet) on the behavior of each pair of modes from the wave packet of the perturbation. This is the effect of forced interference imposed by the main wave. However, the simple calculation of such waves by means of space monitoring due to the small viewing area (frame) may also be inaccurate. Once formed, such waves are able to drift over considerable distances. Moreover, they may well fall into the next viewing frame, which will unreasonably increase the number of such waves in the entire observation zone. That is, estimates of the number of such modes can be overestimated.

As shown in [7, 8], the shape of the packet, which contains a wave of anomalous sweep, more than three times the average span of wave motion, is a train of three waves, similar to Peregrin's autowave [9]. V.E. Zakharov's remark that there are other types of anomalous waves of a given nature [10,11], based on observations [12,13], is explained by the results of [14], where it is shown that converging wave fronts can certainly generate more powerful abnormal perturbations of a different topology.

Authors are grateful to prof. V.A. Buts for discussing the results of the work.

\section{ORCID IDs}

DVolodymyr M. Kuklin http://orcid.org/0000-0002-0310-1582, (DEugen V. Poklonskiy https://orcid.org/0000-0001-5682-6694

\section{REFERENCES}

[1] V.I. Karpman, Нелинейные волны в диспергирующих средах [Nonlinear waves in dispersing media] (Nauka, Moscow, 1975), pp. 175. (in Russian)

[2] M.J. Lighthill, IMA Journal of Applied Mathematics, 1(3), 269-306 (1965), https://doi.org/10.1093/imamat/1.3.269.

[3] E.V. Belkin. PhD-thesis (V.N. Karazin Kharkiv National University, Kharkiv, 2010), pp. 150. (in Russian)

[4] E.V. Belkin, A.V. Kirichok A.V. and V.M. Kuklin, VANT Ser. Plasma electronics and new acceleration methods, 68(4), 291-295 (2010).

[5] E.V. Belkin, A.V. Kirichok, V.M. Kuklin and A.V. Priymak, East Eur. J. Phys. 1(2), 4-39 (2014). (in Russian).

[6] V.M. Chernousenko, V.M. Kuklin, I.P. Panchenko and V.M. Vorob'ev, in IV Int. Workshop on Nonlinear and Turbulent Proc. In Physics. (Singapore, World Scientific, 1990), 2, pp. 776-803.

[7] V.M. Kuklin. Избранные главы. Теоретическая физика. [Selected Chapters. Theoretical Physics] (V.N. Karazin Kharkiv National University, Kharkiv, 2018), pp. 224. (in Russian)

[8] A. Chabchoub, N. Hoffmann and N. Akhmediev, Physical Review Letters, 106, 204502 (2011), https://doi.org/10.1103/PhysRevLett.106.204502.

[9] D. Peregrine. The ANZIAM Journal, 25(1), 16-43 (1983), https://doi.org/10.1017/S0334270000003891.

[10] V.E. Zakharov, Eur. J. Mech. B Fluids. 18(3), 327-344 (1999).

[11] A.I. Dyachenko and V.E. Zakharov, JETP Lett. 81(6), 255-259 (2005), https://doi.org/10.1134/1.1931010.

[12] A.A. Kurkin and E.N. Pelinovsky, Волны убийцы: Факты, теория и моделирование. [Killer waves: facts, theory and modeling], (UNN, Nizhny Novgorod, 2004). (in Russian).

[13] P. Stansell, Ocean Engineering, 32(8-9), 1015-1036 (2005), https://doi.org/10.1016/j.oceaneng.2004.10.016.

[14] A. Chabchoub, N. Hoffmann, M. Onorato, and N. Akhmediev, Physical Review X, 2, 011015 (2012), https://doi.org/10.1103/PhysRevX.2.011015.

\section{ДО ПИТАННЯ ПРО ЧАСТОТУ І ПРОСТОРОВУ ПЕРІОДИЧНІСТЬ ПОЯВИ ХВИЛЬ АНОМАЛЬНОЇ АМПЛІТУДИ В ОКЕАНІ \\ В.М. Куклін, Е.В. Поклонский \\ Харківський національний університет ім. В. Н. Каразіна, Харків, Украӥна \\ м. Свободи 4, м. Харків, Україна, 61022}

В роботі показано, що хвилі аномальної амплітуди є довгоживучими утвореннями. Вони дрейфують в напрямку хвильового руху з груповою швидкістю хвильового пакета, яка вдвічі менше фазової швидкості основної хвилі. Розмах хвилі (відстань від горба до западини) аномальної амплітуди більш ніж втричі перевершує середнє значення розмахів хвильового руху. В результаті модуляційної нестійкості цієї хвилі формується спектр збуджень, енергія якого вдвічі більше енергії основної хвилі в розвиненому режимі процесу. Просторовий розмір хвильового пакета практично не змінюється, амплітуда розмаху в максимумі спочатку наростає, потім поступово зменшується. Число таких хвиль в зонах сильного вітрового впливу значно більше, ніж це дозволяє статистика випадкових інтерференційних процесів. Це обумовлено впливом основної хвилі (iї 
амплітуда залишається помітно більше амплітуд кожної з мод хвильового пакета) на поведінку кожної пари мод 3 хвильового пакета обурення. У лабораторній системі тривалість виникнення аномальної хвилі якісно збігається 3 часом існування автоволни Перегрина. Хоча слід зазначити, що автохвиля Перегрина відповідає іншої фізичної реальності, де дисперсія хвилі слабка. Гравітаційні поверхневі хвилі мають сильну дисперсією і рівняння НУШ в цьому випадку помітно модифікується. Однак в системі спокою хвильового пакету, (яка рухаеться відносно лабораторної системи) час життя хвилі аномальної амплітуди істотно більше. Відстань, яку проходить хвильової пакет з аномальним розмахом, відповідає кільком сотням довжин хвиль і може досягати сотень кілометрів. Простий підрахунок таких хвиль засобами космічного моніторингу через невелику зону (кадр) перегляду може виявитися неточним. Одного разу з'явившись, такі хвилі здатні дрейфувати на значні відстані. При цьому вони цілком можуть потрапити в наступний кадр перегляду. Тобто оцінки числа таких мод можуть бути завищені.

КЛЮЧОВІ СЛОВА: довгоживуча хвиля аномально амплітуди, океанське хвилювання, модуляційна нестійкість

\section{К ВОПРОСУ О ЧАСТОТЕ И ПРОСТРАНСТВЕННОЙ ПЕРИОДИЧНОСТИ ПОЯВЛЕНИЯ ВОЛН АНОМАЛЬНОЙ АМПЛИТУДЫ В ОКЕАНЕ \\ В.М. Куклин, Е.В. Поклонский}

Харьковский национальный университет имени В. Н. Каразина, Харьков, Украина пл. Свободы 4, г. Харьков, Украина, 61022

В работе показано, что волны аномальной амплитуды являются долгоживущими образованиями. Они дрейфуют в направлении волнового движения с групповой скоростью волнового пакета, которая вдвое меньше фазовой скорости основной волны. Размах волны (расстояние от горба до впадины) аномальной амплитуды в результате модуляционной неустойчивости, более чем втрое превосходит среднее значение размахов волнового движения. В результате модуляционной неустойчивости этой волны формируется спектр возмущения, энергия которого вдвое больше энергии основной волны в развитом режиме процесса. Пространственный размер волнового пакета практически не меняется, амплитуда размаха в максимуме сначала нарастает, потом постепенно убывает. Число таких волн в зонах сильного ветрового воздействия значительно больше, чем это разрешает статистика случайных интерференционных процессов. Это обусловлено влиянием основной волны (ее амплитуда остается заметно больше амплитуд каждой из мод волнового пакета) на поведение каждой пары мод из волнового пакета возмущения. В лабораторной системе продолжительность возникновения аномальной волны качественно совпадает с временем существования автоволны Перегрина. Хотя следует отметить, что автоволна Перегрина отвечает иной физической реальности, где дисперсия волны слабая. Гравитационные поверхностные волны обладают сильной дисперсией и уравнение НУШ в этом случае заметно модифицируется. Однако в движущейся относительно лабораторной системе покоя волны время жизни волны существенно больше. Расстояние, которое проходит волновой пакет с сохраняющимся аномальным размахом, по крайней мере равно нескольким сотням длин волн и может достигать сотен километров. Простой подсчет таких волн средствами космического мониторинга из-за небольшой зоны (кадра) просмотра может оказаться неточным. Однажды образовавшись, такие волны способны дрейфовать на значительные расстояния. При этом они вполне могут попасть в следующий кадр просмотра. То есть оценки числа таких мод могут быть завышены.

КЛЮЧЕВЫЕ СЛОВА: долгоживущая волна аномально амплитуды, океанское волнение, модуляционная неустойчивость 